\title{
IMPLEMENTASI PASAL 33 AYAT 3 UUD 1945 \\ DALAM BERBAGAI PERUNDANG-UNDANGAN TENTANG SUMBERDAYA ALAM ${ }^{1}$
}

Oleh :

Tjok Istri Putra Astiti, Gusti Ayu Putri Kartika, Anak Agung Istri Ari Atu Dewi

\begin{abstract}
This study aims to : 1) determine the translation of Article 33, paragraph 3 of the 1945 Constitution in a variety of legislation on natural resources, 2 ) analyze the synchronization of several provisions in the legislation on the natural resources, espicially related to legal community participation and sanctions, and 3) analyze the implications of insynchronization between the regulations of natural resource.

This research is a normative legal research is implemented using the statute approach. The main object of study is the primary legal materials in the form of legislation on natural resources.

The results showed that, in principle, the essence of Article 33 paragraph 3 of the 1945 Constitution, about the "earth, water, and space, and the natural riches contained therein, shall be controlled by the state and used for the greatest welfare of the people. " has been translated into various statutory provisions of natural resources.

There is synchronization between the various legislation, among other things : state control of natural resource management authorizes local governments, and the types of sanctions imposed against violations to the various regulations, namely sanction of imprisonment, confinement and fine. However, there is not synchronization related to the delivery of state control of the rights to the indigenous people (legal community)and about magnitude of sanctions, there are countless monthly, there are countless decades. Likewise, regarding the fine penalties, there is a very lightweight ( $R p$ 10,000) some are up to $R p$ 15.000.000.000,-

The existence of the insynchronization may be implicated on the participation of the legal community (indigeneus people) in managing the local natural resources and lack of legal positiveness (kepastian hukum) in law enforcement for violations of the various regulations on these resources.
\end{abstract}

\section{Key Word : Implementation, 1945 Constitution, Natural resource}

Karya ilmiah ini merupakan hasil penelitian yang di biayai dari dana Dipa BLU Program Studi Magister (S2) Ilmu Hukum PPS UNUD dengan SK Rektor nomor 2113/UN.14.4/HK./2014, telah di presentasikan dalam seminar/FGD di Program Magister (S2) Ilmu Hukum pada tanggal 31 Oktober. 2014

Peneliti adalah Guru Besar dan dosen pada Program Studi Magister (S2) Ilmu Hukum Program Pascasarjana UNUD 


\section{PENDAHULUAN}

\subsection{Latar Belakang Masalah}

Sumber daya alam yang berupa bumi, air, dan ruang angkasa saat ini banyak mengalami masalah, apakah kerusakan, pencemaran, polusi, banjir, tanah longsor, dan sebagainya yang tidak henti-hentinya menimbulkan bencana alam bagi kehidupan manusia. Di samping menimbulkan bencana alam tidak sedikit juga sumber daya alam menimbulkan bencana sosial. Sumber daya alam yang semakin terbatas baik yang ada di permukaan bumi maupun yang ada di perut bumi seringkali menjadi rebutan dan menimbulkan sengketa, kadangkala disertai kekerasan. Selain itu, sumber daya alam seringkali juga menimbulkan bencana dibidang kesehatan seperti timbulnya wabah penyakit dalam berbagai bentuk

Keberadaan sumber daya alam yang di satu pihak semakin langka dan di pihak lain dibutuhkan oleh umat manusia dan makhluk hidup lainnya itu, perlu dijaga, dilestarikan dan diberdayakan supaya tetap berhasil guna untuk kehidupan manusia. Oleh karena itu, manusia yang menggunakan sumber daya alam tersebut dituntut untuk bertindak arif dan bijaksana untuk tetap menjaganya sehingga sumber daya alam tetap berfungsi dengan baik bagi kehidupam makluk ciptaan Tuhan.

Oleh karena demikian pentingnya arti dan makna Sumber daya alam (SDA) bagi kehidupan makhluk, khususnya manusia di dunia ini, maka sumber daya alam itu sudah sepantasnya diatur secara hukum, apalagi negara Indonesia adalah negara hukum. Di Indonesia, prihal sumber daya alam sebenarnya secara umum sudah diatur dalam UUD 1945 pasal 33 ayat 3 yang menagatur sebagai berikut:

"Bumi dan Air dan kekayaan alam yang terkandung di dalamnya dikuasai oleh negara dan dipergunakan untuk sebesar-besarnya kemakmuran rakyat".

Ketentuan pasal 33 ayat 3 UUD 1945 itu sudah dijabarkan dalam berbagai perundangundangan di bawahnya, seperti UU Pokok Agraria (UUPA), yang mengatur tentang pertanahan, Undang-Undang Kehutanan, Undang-Undang Sumber daya Air, UndangUndang Pertambangan, dan lain sebagainya. Persoalannya, apakah ada sinkronisasi antara undang-undang yang satu dengan yang lain dalam mengatur sumber daya alam. Kalau terjadi ketidaksinkronan, masalah kepastian hukum akan sulit diwujudkan. Persoalan ini perlu mendapat pengkajian secara lebih mendalam karena sumber daya alam diperuntukkan bagi kesejahteraan umat manusia dan makhluk hidup lainnya.

\subsection{Rumusan Masalah}

Berdasarkan latar belakang di atas, permasalahan yang diajukan dalam penelitian ini adalah :

1. Bagaimana ketentuan pasal 33 ayat 3 UUD 1945 dijabarkan dalam berbagai perundang-undangan yang terkait dengan sumber daya alam?

2. Apakah ada sinkronisasi/ ketidaksinkronan antara ketentuan 
berbagai perundang-undangan terkait dengan pengelolaan sumberdaya alam?

3. Bagaimana implikasi dalam hal terjadi ketidaksinkronan dalam pengaturan pemanfaatan sumber daya alam?

\section{METODE PENELITIAN}

\section{Jenis Penelitian}

Penelitian ini merupakan penelitian hukum normatif yang fokus kajiannya adalah masalah sinkronisasi ketentuan perundang-undangan yang mengatur tentang sumberdaya alam. Bahan-bahan hukum yang akan dikaji adalah :

1. Undang-Undang Dasar 1945

2. Undang-Undang Pokok Agraria (Undang-Undang No. 5 tahun 1960)

3. Undang-Undang tentang Kehutanan (Undang-Undang No. 41 Tahun 1999)

4. Undang-Undang tentang Sumber Daya Air (Undang-Undang Republik Indonesia Nomor 7 Tahun 2004).

5. Undang-Undang tentang

Pertambangan, Mineral dan Batubara (Undang-undang Republik Indonesia Nomor 4 Tahun 2009)

6. Undang-Undang tentang Perikanan (Undang-Undang Republik Indonesia Nomor 45 tahun 2009)

\section{Pendekatan}

Pendekatan yang digunakan adalah pendekatan kualitatif dan perundangundangan (statute approarch).
Langkah-langkah penelitian

Langkah-langkah penelitian dimulai dari melakukan invetarisasi perundangundangan yang mengatur tentang sumberdaya. Setelah perundang-undangan tersebut diinventarisasi, langkah selanjutnya adalah menelaah penjabaran pasal 33 ayat 3 UUD 1945 dalam masing-masing peraturan perundang-undangan tersebut. Dari hasil penjabaran tersebut barulah kemudian dilakukan analisis tentang sinkronisasi antar perundang-undangan tersebut, dan selanjunya dilakukan pengkajian tentang implikasi ketidak sinkronnan ketentuan perundang-undangan satu dengan yang lain, Dalam proses analisis bahan hukum digunakan pendekatan kualitatif dan matrik.

\section{HASIL DAN PEMBAHASAN}

Indonesia diakui sebagai suatu negara yang mempunyai kekayaan alam berlimpah, seperti sumber daya mineral, sumber daya air, sumber daya hutan, dan lain-lain Sumber kekayaan alam tersebut dianugrahkan Tuhan kepada rakyat dan bangsa Indonesia untuk kesejahteraan dan kemakmuran rakyat sebagaimana diamanatkan dalam pembukaan UUD 1945. Oleh karena kekayaan alam tersebut diperuntukkan bagi kesejahteraan dan kemakmuran seluruh rakyat, maka penguasaan dan pemanfaatannya diatur dalam konstitusi dan dalam berbagai produk perundang-undangan nasional. Ideologi dan politik hukum tentang penguasaan dan pemanfaatan sumber daya alam tersebut tercermin dalam Pasal 33 ayat 3 Undang- 
Undang Dasar 1945, yang menyatakan sebagai berikut:

"Bumi, air dan kekayaan alam yang terkandung di dalamnya dikuasai oleh Negara dan dipergunakan sebesarbesarnya untuk kemakmuran rakyat"

Terkait dengan ideologi dan politik hukum tentang penguasaan dan pemanfaatan sumberdaya alam sebagaimana dinyatakan dalam ketentuan pasal 33 ayat 3 UUD 1945 tersebut, Nurjaya mempertanyakan apakah selama ini kekayaan alam tersebut telah membawa nikmat dan telah mengantarkan rakyat dan bangsa Indonesia ke tingkat kesejahteraan dan kemakmuran sebagaiman dicita-citakan oleh Pembukaan UUD 1945? Nurjaya sendiri menjawab bahwa yang terjadi justru proses pemiskinan struktural yang berlangsung secara sistematik. ${ }^{3}$

Pandangan Nurjaya ada benarnya, karena selama ini dapat dilihat bahwa daerah-daerah yang kaya akan sumberdaya alam yang telah diekplotasi untuk pembangunan nasional, ternyata wilayah tersebut tidak memperoleh manfaat dari pemanfaatan sumberdaya alam yang ada di wilayahnya. Tidaklah salah apabila Mubariq Ahmad menyatakan bahwa : "daerah tidak memperoleh manfaat yang memadai dari pemanfaatan sumberdaya alamnya". ${ }^{4}$ Penggunaan sumberdaya alam

I Nyoman Nurjaya, 2000, Pengelolaan Sumberdaya Alam dalam Perspektif Antropologi Hukum, Prestasi Pustaka, Jakarta, halaman 149-150

4 Mubariq Ahmad, 1994, Sumberdaya Lokal untuk Masyarakat Lokal: Sebuah Impian, halaman 12 untuk sebesar-besarnya kemakmuran rakyat, sebagaimana dirumuskan dalam UUD 1945 itu, mestinya dimaknai bahwa rakyat yang dimaksud adalah rakyat dimana sumberdaya alam itu berada, minimal daerah itu mendapat kontribusi yang memadai untuk kesejahterraan dan kemakmuran masyarakat setempat.

Proses pemiskinan dan tidak memadainya kontribusi kepada masyarakat lokal atas pemanfaatan sumberdaya alam yang ada di wilayahnya seringkali menimbulkankonflikataupun sengketaantara pihak pemerintah, investor yang mendapat ijin pemanfaatan sumberdaya alam dengan pihak masyarakat lokal. Konflik semacam ini sebenarnya dapat dihindari apabila masyarakat lokal dilibatkan sejak tahapan perencanaan sampai pada pelaksanaan dan penilaian terhadap pemanfaatan sumberdaya alam yang ada di lingkungan wilayahnya. Peranserta masyarakat memang sudah diatur dalam berbagai peraturan perundangundangan, antara lain dalam Undang-Undang Pokok Agraria (UUPA) dan Undang-Undang tentang Kehutanan (Undang-Undang No. 41 Tahun 1999), Akan tetapi dalam pelaksanaannya, seringkali masyarakat hanya dilibatkan dalam pelaksanaannya sedangkan dalam perencanaan dan penilaian terkait dengan pemanfaatannya pemerintah melakukannya secara sepihak, sehingga menimbulkan ketidakpuasan pada masyarakat yang berpotensi menimbulkan konflik.

Konflik ataupun sengketa terkait dengan pemanfaatan sumberdaya alam telah 
terjadi di berbagai tempat di Indonesia. Konflik/sengketa tersebut disebabkan oleh adanya pelanggaran-pelanggaran baik dari pihak yang memegang ijin pengelolaan, maupun oleh masyarakat. Pelanggaranpelanggaran yang terjadi dapat berbentuk antara lain, membakar hutan, menebang pohon dan memiliki hasil hutan secara illegal, memiliki hasil hutan tanpa surat keterangan, mengembalakan ternak dalam kawasan hutan, membuang benda-benda yang berbahaya, membawa satwa dan tumbuh-tumbuhan yang dilindungi, dan sebagainya $^{5}$

Salah satu contoh kasus pengelolaan sumberdaya alam oleh masyarakat lokal yang patut dijadikan cotoh, adalah penguasaan dan pengelolaan sumberdaya alam (tanah, dan hutan) yang ada pada masyarakat Tenganan Pagringsingan, Kabupaten Karangasem, Bali, dimana tanah, hutan dan hasil hutan yang ada di wilayahnya memberikan kontribusi yang cukup besar kepada masyarakat setempat. Masyarakat setempat juga menerapkan aturan lokal (awig-awig) untuk mengawasi dan menjaga hutan supaya tetap berfungsi sebagaimana mestinya bagi kesejahteraan mereka. $^{6}$

H. S. Salim, SH.MS, 2002, Dasar-Dasar Hukum Kehutanan, Sinar Grafika, Jakarta, halaman 158- 159 Baca Tjok Istri Putra Astiti, dkk 2011, Dampak Perkembangan Ekonomi Pariwisata terhadap Hukum Tanah di Desa Tenganan Pagringsingan, Laporan Penelitian, Fakultas Hukum, Universitas Udayana, Denpasar, halaman 18-20. Baca pula Tjok Istri Putra Astiti, dkk. 2013. “Tourism Development and Customay Land Law in Bali: The Case of The Tenganan Pagringsingan Village" dalam Soutthwestern Journal of International Law, Volume XX Number 1, halaman 125-128.
Di pihak lain contoh kasus tentang penggunaan kawasan hutan secara ilegal dikemukakan oleh Suardana dalam tesisnya yang berjudul : "Implementasi Prinsip Perlindungan Hutan dalam Penanggulangan Illegal Occupation di Kawasan Hutan (Studi Kasus pada Illegal Occupation di Tahura Ngurah Rai) ${ }^{7}$

Konflik-konflik yang terkait dengan pemanfaatan sumberdaya alam tidak saja terjadi dalam tataran empirik, akan tetapi dapat pulan terjadi dalam tataran normatif, artinya terjadi ketidak sesuaian antara norma yang satu dengan yang lain, seperti misalnya antara Undang-Undang Pokok Agararia yang mengatur masalah pertanahan, dan Undang-Undang tentang Kehutanan yang mengatur tentang hutan dan dengan sendirinya juga menyangkut tanah di mana hutan itu tumbuh. Demikian juga perundang-undangan 1;ainnya yang mengatur sumberdaya alam yang satu sama lain saling bersinggungan. Kajian normatif tentang hal tersebut diatas, diajikan dalam hasil penelitian di bawah ini

Penjabaran Pasal 33 ayat 3 UUD 1945 dalam berbagai Perundangundangan tentang Sumberdaya Alam

\footnotetext{
I Wayan Suardana, 2011, “ Implementasi Prinsip Perlindungan Hutan dalam Penanggulangan Illegal Occupation di Kawasan Hutan (Studi Kasus Illegal Occupation di Tahura Ngurahrai), Tesis Program S2 Ilmu Hukum Program ascasarjana Universitas Udayana, Denpasar,, halaman 156.
} 
Bumi dan air dan kekayaan alam yang terkandung di dalamnya di kuasai oleh Negara dan dipergunakan untuk sebesar-besar kemakmuran rakyat.

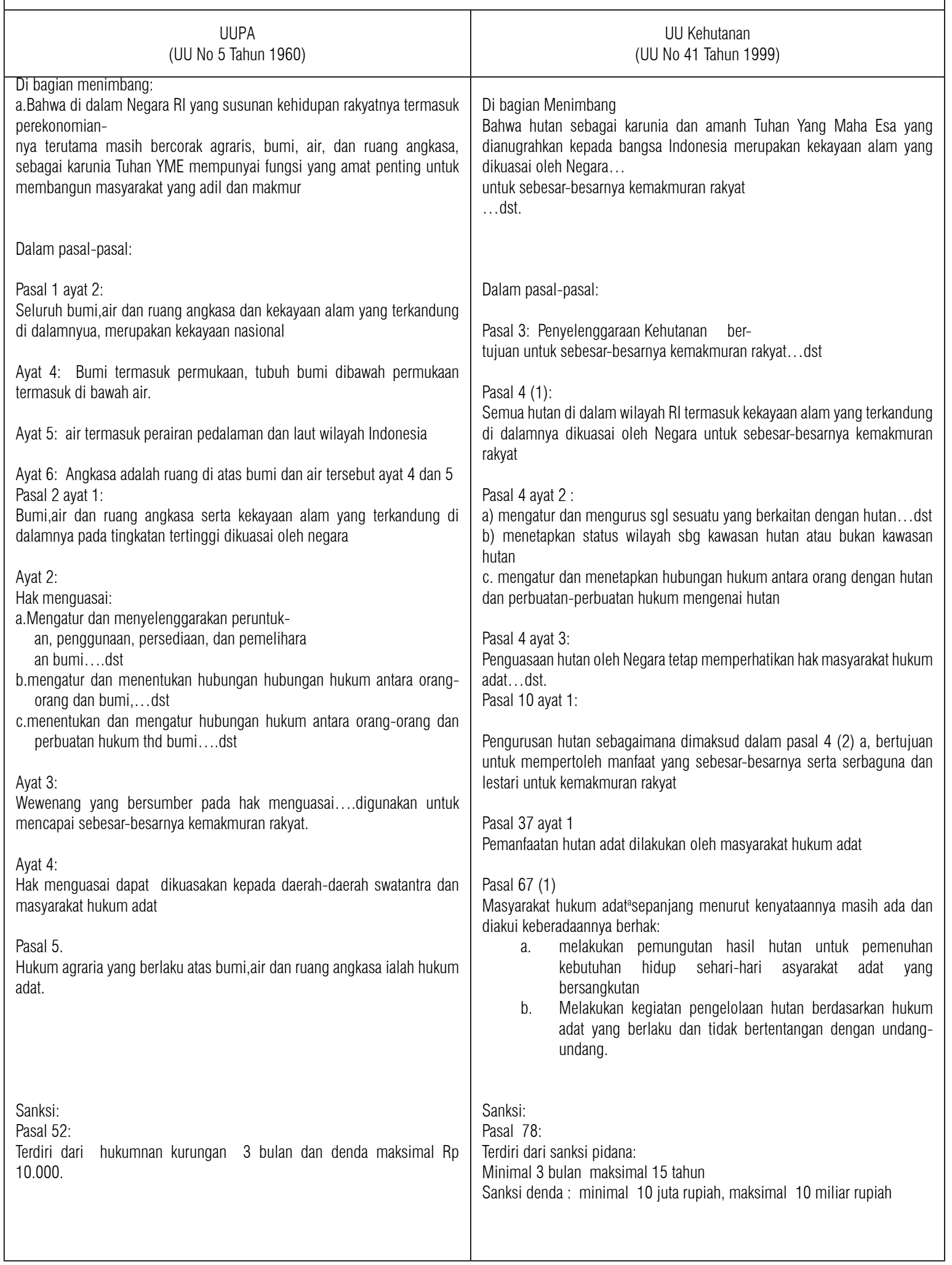


Bumi dan air dan kekayaan alam yang terkandung di dalamnya di kuasai oleh Negara dan dipergunakan untuk sebesar-besar kemakmuran rakyat.

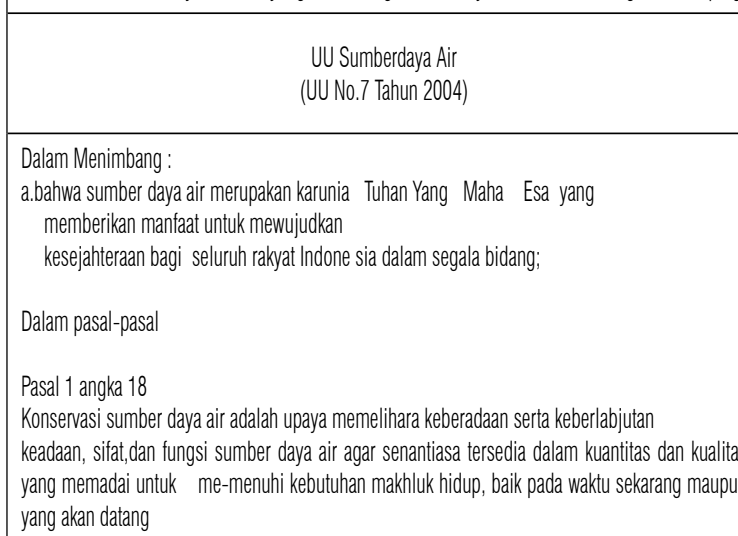

Pasal 1 angka 19

Pendayagunaan sumber daya air adalah upaya penatagunaan, penyediaan, peng- gunaan, pengembangan, dan pengusahaan sumber daya air secara optimal agar ber-hasil guna dan berdayaguna.

Pasal 2

Sumber daya air dikelola berdasarkan asas kelestarian, keseimbangan, kemanfaatan umum, keterpaduan dan keserasian, keadilan, kemandirian, serta transparansi dan akuntabilitas.

Pasal 3

Sumber daya air dikelola secara menyeluruh, terpadu, dan berwawasan lingkungan hidup dengan tujuan me- wujudkan kemantaatan sumber daya air yang berkelanjutan untuk sebesar-besar kemakmuran rakyat.

Pasal 6

(1) Sumber daya air dikuasai oleh negara dan dipergunakan untuk sebesar-besar kemakmuran rakyat.

2) Penguasaan sumber daya air sebagai -mana dimaksud pada ayat (1) diseleng- garakan oleh Pemerintah dan/atau pemerintah daerah dengan tetap me -ngakui hak ulayat masyarakat hukum adat setempat dan hak yang serupa dengan itu, sepanjang tidak bertentang an dengan kepentingan nasional dan peraturan perundang-undangan.

(3) Hak ulayat masyarakat hukum adat atas sumber daya air sebagaimana dimak- sud pada ayat(2) tetap diakui sepan- jang kenyataannya masih ada dan telah dikukuhkan dengan peraturan daerah setempat.

(4) Atas dasar penguasaan negara sebagai- dimaksud pada ayat (1) ditentu kan hak guna air.

Pasal 11

(1) Untuk menjamin terselenggaranya pengelolaan sumber daya air yang dapat memberikan manfaat yang sebesar-besarnya bagi kepentingan masyarakat dalam segala bidang kehidupan disusun pola pengelolaan sumber daya air.

Sanksi

Pasal 94 mengatur tentang sanksi pidana penjara dan denda.

(1) Pidana Penjara 9 tahun dan denda : Rp 1.500 .000 .000

(2) Pidana penjara 6 tahun dan Denda Rp 1.000.000.000

(3) Pidana Penjara mak. 3 tahun dan denda : Rp 500.000.000
UU Pengelolaan Wilayah Pesisir dan Pulau-pulau kecil (UU No 1 TH 2014)

Dalam Menimbang:

a.bahwa wilayah pesisir dan pulau-pulau kecil dikuasai oleh negara dan dipergunakan untuk sebesarbesarnya kemakmuran rakyat sebagai-mana diamanatkan dalam Undang-Undang Dasar Negara Republik Indonesia Tahun 1945

Dalam pasal-pasal

Pasal 1 angka 10

Kawasan Strategis Nasional Tertentu adalah Kawasan yang terkait dengan kedaulatan negara, pengendalian lingkungan hidup, dan/atau situs warisan dunia, yang pengembangannya diprioritaskan bagi kepentingan nasional.

Pasal 21

(1) Pemantaatan ruang dan sumber daya perairan pesisir dan perairan pulau-pulau kecil pada wilayah masyarakat hukum adat menjadi ke- wenangan Masyarakat Hukum Adat setempat.

(2) Pemanfaatan ruang dan sumber daya Perairan Pesisir dan perairan pulau-pulau kecil sebagai mana dimaksud pada ayat (1) dilakukan de-ngan mempertimbangkan kepentingan nasio- nal dan sesuai dengan ketentuan peraturan perundang-undangan."

Pasal 60

(1) Dalam Pengelolaan Wilayah Pesisir dan Pulau -Pulau Kecil, Masyarakat mempunyai hak untuk:

a.a.memperoleh akses terhadap bagian Perairan Pesisir yang sudah diberi Izin Lokasi dan Izin Pengelolaan;

b mengusulkan wilayah penangkapan ikan

secara tradisional ke dalam RZWP-3-K;

c. mengusulkan wilayah Masyarakat Hukum Adat ke dalam RZWP-3-K;

d melakukan kegiatan pengelolaan umberdaya Pesisir dan Pulau-Pulau Kecil berdasarkan hukum adat yang berlaku dan tidak bertentang-

an dengan ketentuan peraturan perundang- undangan;

e. memperoleh manfaat atas pelaksanaan penge- Iolaan Wilayah Pesisir dan Pulau-Pulau Kecil;

f.f memperoleh informasi berkenaan dengan

Pengelolaan Wilayah Pesisir dan Pulau-Pulau Kecil;

g.mengajukan laporan dan pengaduan kepada pihak yang berwenang atas kerugian yang menimpa dirinya yang berkaitan dengan pelaksanaan Pengelolaan Wilayah Pesisir dan

Pulau-Pulau Kecil;

h.menyatakan keberatan terhadap rencana pengelolaan yang sudah diumumkan dalam jangka waktu tertentu;

i melaporkan kepada penegak hukum akibat dugaan pencemaran, pencemaran, dan/atau perusakan Wilayah Pesisir dan Pulau-Pulau Kecil yang merugikan kehidupannya;

j. mengajukan gugatan kepada pengadilan er-hadap berbagai masalah Wilayah Pesisir dan PulauPulau Kecil yang merugikan kehidupan- nya;

k. memperoleh ganti rugi; dan

I. mendapat pendampingan dan bantuan hukum terhadap permasalahan yang dihadapi dalam Pengelolaan Wilayah Pesisir dan Pulau Kecil 
Bumi dan air dan kekayaan alam yang terkandung di dalamnya di kuasai oleh $\mathrm{N}$ egara dan dipergunakan untuk sebesar-besar kemakmuran rakyat.

UU Pertambangan, Mineral dan Batubara (Undang RI Nomor 4 tahun 2009

Undang-Undang RI Nomor 45 Tahun 2009 tentang Perubahan Atas

Bagian Menimbanga

a) Bahwa mineral dan batubara yang ter -kandung dalam wilayah hukum per -tambangan Indonesia merupakan kekayaan alam tak terbarukan sebagai karunia Tuhan YME... pengelolaannya harus dikuasai oleh Negara... untuk mencapai kemakmuran dan kesejahtra- an rakyat secara berkeadilan.

Dalam pasal-pasal:

Pasal 4 ayat 1 :

Mineral dan batubara sbg SDA yang tak terbarukan merupakan kekayaan nasional yang dikuasai oleh negara untuk sebesar-besarnya kemakmuran rakyat

\section{Ayat 2) :}

Penguasaan mineral dan batubara sebagai- mana dimaksud pada ayat 1 diselenggara- kan oleh pemerintah dan/pemerintah daerah

Sanksi :

Pasal 151 :

Mengatur tentang sanksi administrartif berupa peringatan tertulis; penghentian sementara sebagaian/seluruh kegiatan produksi dan pencabutan ijin

Pasal 158 :

Sanksi pidana : maksimal 10 tahun dan denda maksimal 10 miliar.

asal 159

Pidana penjara maksimal 10 tahun dan denda maksimal 10 miliar

Pasal 160

Kurungan maksimal satu tahun, atau denda paling banyal Rp 200. 000.000

Pasal 161: pidana penjara maksimal 10 tahun, denda maksimal 10 miliar

Bagian Menimbang

(a) bahwa perairan yang berada dalam kedaulat an Negara Kesatuan Republik Indonesia dan Zone Ekonomi Eksklusif Indonesia serta laut lepas mengandung sumber daya ikan yang potensial dan sebagai lahan pembudi-dayaan ikan merupakan berkah dari Tuhan Yang Maha Esa yang diamanatkan kepada bangsa Indonesia ... untuk dimanfaatkan sebesar-besarnya bagi kesejahtraan dan kemakmuran rakyat Indonesia.

Dalam pasal-pasal

Pasal 1 angka (1)

Menentukan bahwa perikanan adalah semua kegiatan yang berhubungan dengan pengelolaan dan pemanfaatan sumber daya ikan dan lingkungannya mulai dari pra- produksi, produksi, pengolahan sampai dengan pemasaran yang dilaksanakan dalam suatu sistem bisnis perikanan.

Angka (7)

Perairan Indonesia adalah laut territorial Indonesia beserta perairan kepulauan dan perairan pedalamannya.

Angka (21)

Zone Ekonomi Eksklusif Indonesia yang selanjutnya disebut ZEEI, adalah jalur di luar dan berbatasan dengan laut teritorial Indonesia sebagaimana ditetapkan berdasarkan undang-undang yang berlaku tentang perairan Indonesia yang meliputi dasar laut, tanah dibawahnya, dan air di atasnya dengan batas terluar 200 ( dua ratus) mil laut yang diukur dari garis pangkal laut territorial Indonesia.

Ketentuan Pasal 9

Ayat (1) setiap orang dilarang memiliki, menguasai, membawa, dan/atau menggunakan alat penangkapan dan/atau alat bantu penangkapan ikan yang mengganggu dan merusak keberlanjutan sumber daya ikan di kapal penangkapan ikan di wilayah pengelolaan perikanan Negara Republik Indonesia.

Sanksi

Pasal 85

menetukan bahwa setiap orang yang dengan sengaja memiliki, menguasai, membawa, dan /atau menggunakan alat penangkap ikan dan/atau alat bantu penangkapan ikan yang mengganggu dan merusak keberlanjutan sumber daya ikan di kapal penangkap ikan di wilayah pengelolaan perikanan Negara Republik Indonesia sebagaimana dimaksud dalam Pasal 9 dipidana dengan pidana penjara paling lama 5 (lima) tahun dan denda paling banyak Rp 2. 000. 000. 000.,00 (dua miliar rupiah). 
Berdasarkan hasil deskripsi tersebut di atas, dapat dilihat bahwa jiwa pasal 33 ayat 3 UUD 1945 telah dijabarkan dengan jelas dalam bagian pertimbangan dan pasalpasal dari perundang-undangan tersebut di atas. Penjabaran tersebut disusun dengan rumusan yang berbeda-beda namun dapat di dalamnya terkandung inti yang sama, yaitu bahwa sumberdaya alam, baik itu tanah, air, hutan, hasil tambang dan lain sebagainya dikuasai ole negara dan dipergunakan untuk sebesar-besarnya kemakmuran rakyat. Apakah tujuan penguasaan oleh negara dan pemanfaatannta untuk sebesarbesarnya kemakmuran rakyat sudah dapat diwujudkan? Hal ini masih memerlukan penelitian lanjutan secara empirik.

\subsection{Sinkronisasi Perundang-undangan tentang Sumberdaya Alam dalam Konteks Masyarakat Hukum Adat dan Sanksi-sanksi terhadap Pelanggaran Perundang-undangan tersebut}

Analisis tentang sinkronisasi antara perundang-undangan tersebut diatas (UUPA, UU Kehutanan, UU tentang Sumberdaya Air, UU tentang Wilayah Pesisir dan Pulau-pulau Kecil, Uudang-undang tentang Pertambangan, Mineral dan Batubara serta Undang-Undang tentang Perikanan, hanya difokuskan pada bagian menimbang, beberapa pasal khususnya yang terkait dengan pelibatan masyarakat hukum adat dan pasal-pasal yang terkait dengan sanksi

Berdasarkan deskripsi pada bagian menimbang, tampaknya semua perundang- undangan tersebut di atas sinkron atau ada kesesuaian satu dengan yang lain, dalam arti bahwa sumberdaya alam yang diatur dalam masing-masing undang-undang, secara jelas dikatakan dikuasai oleh Negara dan dimanfaatkan sebesar-besarnya untuk kemakmuran rakyat.

Apabila dikaji beberapa pasal dari perundang-undangan tersebut dapat dilihat di satu pihak ada kesinkronan dan di pihak lain ada ketidak sinkronan. Hal-hal yang menunjukkan kesesuaian antara undangundang yang satu dengan undang-undang yang lainnya, adalah dalam hal adanya hak menguasai oleh negara itu yang dikuasakan kepada Pemerintahan Daerah. Di pihak lain, ketidak sinkronan terlihat dari adanya beberapa undang-undang yang secara jelas menyatakan bahwa pelaksanaan hak penguasaan sumberdaya alam itu di samping dikuasakan kepada Pemerintah Daerah ada juga yang penguasaanya diserahkan kepada masyarakat desa bahkan masyarakat hukum adat serta dengan pengakuan hukum adatnya, seperti halnya Undang-Undang Pokok Agraria dengan jelas menyatakan hal itu dalam pasal 2 ayat 4 , pasal 3 dan pasal 5 UUPA yang masing-masing mengatur sbb:

Pasal 2 ayat 4: Hak menguasai dari Negara tersebut di atas, pelaksanaannya dapat dikuasakan kepada daerah-daerah Swatantra dan masyarakat hukum adat...

Pasal 3 : Dengan mengingat ketentuanketentuan dalam pasal 1 dan 2 pelaksanaan hak ulayat dan hak-hak yang serupa itu dari dari masyarakat-masyarakat hukum adat sepanjang menurut kenyataannya masih ada...dst 
Pasal 5. Hukum agraria yang berlaku atas bumi,air dan ruang angkasa ialah hukum adat.

Demikian juga dalam Undang-Undang Kehutanan antara lain disebutkan dalam pasal 34 sebagai berikut:

"Pengelolaan kawasan hutan untuk tujuan khusus sebagaimana dimaksud dalam pasal 8 dapat diberikan kepada:

a. Masyarakat hukum adat

Pasal 37 ayat 1 :

Pemanfaatan hutan adat dilakukan oleh masyarakat hukum adat yang bersangkutan, sesuai dengan fungsinya

Pasal 67 (1)

Masyarakat hukum adat sepanjang menurut kenyataannya masih ada dan diakui keberadaannya berhak:

a. Melakukan pemungutan hasil hutan untuk pemenuhan kebutuhan hidup sehari-hari masyarakat adat yang bersangkutan

b. Melakukan kegiatan pengelolaan hutan berdasarkan hukum adat yang berlaku dan tidak bertentangan dengan undang-undang.

Dalam Undang-Undang tentang Pengelolaan Sumberdaya Air dalam pasal 6 ayat 2 disebutkan bahwa Penguasaan sumber daya air sebagaimana dimaksud pada ayat (1) diselenggarakan oleh Pemerintah dan/atau pemerintah daerah dengan tetap mengakui hak ulayat masyarakat hukum adat setempat dan hak yang serupa dengan itu, sepanjang tidak bertentangan dengan kepentingan nasional dan peraturan perundang-undangan.
Selanjutnya dalam ayat 3 disebutkan pula bahwa hak ulayat masyarakat hukum adat atas sumber daya air sebagaimana dimaksud pada ayat (2) tetap diakui sepanjang kenyataannya masih ada dan telah dikukuhkan dengan peraturan daerah setempat.

Keberadaan masyarakat adat dan partisipasinya juga diakui dalam UndangUndang tentang Pengelolaan Wilayah Pesisir dan Pulau-Pulau Kecil, khususnya dalam Pasal 21 (1) yang menentukan sebagai berikut: Pemanfaatan ruang dan sumber daya Perairan Pesisir dan perairan pulau-pulau kecil pada wilayah Masyarakat Hukum Adat oleh Masyarakat Hukum Adat menjadi kewenangan Masyarakat Hukum Adat setempat.

Berbeda dengan ke empat undangundang tersebut di atas, dua undang-undang yang disebut terakhir, yaitu Undang-undang tentang Pertambangan, Mineral dan Batubara serta Undang-Undang tentang Perikanan, tidak ada ketentuannya yang mengatur masalah masyarakat hukum adat.

Berkaitan dengan sanksi atas pelanggaran terhadap perundangundangan tersebut di atas, disatu pihak ada kesinkronan dalam hal jenis sanksi berupa sanksi pidana penjara dan denda. Jenis-jenis sanksi ada pula yang bervariasi seperti adanya hukuman kurungan, ataupun sanksi tambahan berupa sanksi administrasi yang bentuknya juga bermacam-macam seperti : pencabutan ijin dan pencabutan status badan hukum, perampasan barang, perampasan keuntungan, dan Pembayaran biaya yang 
timbul akibat dilakukannya tindak pidana. Di pihak lain, ada ketidak sinkronan antara besarnya pidana penjara, dalam arti ada yang sangat ringan berkisar tiga bulan, ada juga yang lamanya puluhan tahun. Demikian juga terkait dengan pidana denda, ada yang besarnya dalam hitungan puluhan ribu, ada juga yang sangat berat dalam hitungan puluhan milyar. Tentang pidana tambahan, juga ada yang mengatur ada yang tidak.

\section{Implikasi}

Adanya ketidak-sinkronan antara undang-undang yang satu dengan undang yang lainnya terkait dengan penyerahan pelaksanaan hak penguasaan oleh Negara atas sumberdaya alam kepada masyarakat hukum adat, dapat berimplikasi pada tingkat partisipasi masyarakat hukum adat dalam pengelolaan sumberdaya alam tertentu, dan pada tataran empirik dapat menimbulkan ketidakpuasan masyarakat lokal (masyarakat hukum adat) tertentu atas pengabaian Negara terhadap peran sertanya dalam hal pengelolaan sumberdaya alam yang ada di lingkungan wilayahnya dan hal ini dapat berpotensi konflik

Adanya tumpang tindih terhadap ruang lingkup pengaturan masalah sumberdaya alam antara undang-undang yang satu dengan yang lain berpotensi pula untuk terjadinya konflik norma antara yang satu dengan yang lain yang selanjutnya berimplikasi pada terjadinya ketidak pastian hukum dalam penegakan hukumnya. Selain itu, adanya gap yang begitu besar antara undang-undang yang satu dengan yang lain terkait dengan besarnya sanksi atas pelanggaran terhadap berbagai perundangundangaan tentang sumberdaya alam, juga dapat berimplikasi pada ketidak pastian dalam penegakan hukum

\section{PENUTUP}

\subsection{Simpulan}

Berdasarkan hasil analisis bahan hukum tersebut diatas, dapat disimpulkan bahwa :

1) Jiwa dari ketentuan pasal 33 ayat 3 Undang-undang Dasar 1945 pada prinsipnya telah dijabarkan dalam bagian menimbang dan ketentuan beberapa pasal masing-masing undangundang yang menjadi obyek kajian

2) Bahwa dari penjabaran beberapa pasal undang-undang yang dimaksud, dapat dilihat di satu pihak adanya sinkronisasi berkaitan dengan pelaksaaan penguasaan pengelolaan sumberdaya alam kepada Pemerintah Daerah, akan tetapi ada ketidak-sinkronan terkait dengan pengakuan dan penyerahan pelaksanaan hak penguasan atas sumberdaya alam kepada masyarakat hukum adat dan hukum adat.

Selain itu, ada pula sinkronisasi terkait dengan jenis-jenis sanksi yang dijatuhkan terhadap kejahatan dan pelanggaran terhadap perundangundangan tersebut, akan tetapi ada ketidak-sinkronisasi pula terkait dengan besarnya sanksi yang satu terkesan terlalu ringan dan di pihak lain terkesan terlalu berat. 
3) Adanya ketidak-sinkronan antara undang-undang yang satu dengan undang-undang tertentu lainnya, khususnya yang terkait dengan masyarakat adat dan sanksi dapat berimplikasi pada tingkat partisipasi masyarakat adat dalam pengelolaan sumberdaya alam dan tidak adanya kepastian hukum dalam penegakan hukum dalam hal terjadi pelanggaran terhadap berbagai perundangundangan tentang sumberdaya alam yang saling bersinggungan tersebut .

\subsection{Saran}

1. Lembaga pembuat undang-undang sebelum membuat suatu undangundang, khususnya terkait dengan sumberdaya alam terlebih dahulu perlu melakukan kajian secara cermat terhadap isi undang-undang yang satu dengan yang lain yang saling berkaitan seperti halnya tentang sumberdaya alam, supaya tidak terjadi konflik norma dan gap yang begitu besar mengenai sanksi, Hal tersebut perlu dilakukan supaya dapat lebih menjamin kepastian hukum dalam menegakkan hukum sehubungan dengan pelanggaran dan kejahatan terhadap berbagai perundangundangan tersebut..

2. Lembaga pembuat undang-undang perlu mengatur secara jelas tentang partisiapasi dan kedudukan masyarakat hukum adat dalam berbagai peraturan perundang-undangan yang mengatur tentang sumberdaya alam.

\section{DAFTAR PUSTAKA}

Ahmad, Mubariq. 1994. Sumberdaya Lokal Untuk Masyarakat Lokal : Sebuah Impian, Konphalindo, Jakarta.

Astiti, Tjok Istri Putra, dkk 2011, Dampak Perkembangan Ekonomi Pariwisata terhadap Hukum Tanah di Desa Tenganan Pagringsingan, Laporan Penelitian, Fakultas Hukum, Universitas Udayana, Denpasar,

Astiti Tjok Istri Putra, dkk. 2013. “Tourism Development and Customay Land Law in Bali: The Case of The Tenganan Pagringsingan Village" dalam Soutthwestern Journal of International Law, Volume XX Number 1,

Nurjaya, I Nyoman. Prof. Dr. SH.MH. Pengelolaan Sumber Daya Alam dalam Perspektif Antropologi Hukum, Prestasi Pustaka, Jakarta.

Salim,H.S.,SH.,MS. 2002, Dasar-Dasar Hukum Kehutanan, Sinar Grafika, Jakarta.

Suardana, I Wayan, 2011. "Implementasi Prinsip Perlindungan Hutan dalam Penanggulangan Illegal Occupation di Kawasan Hutan (Studi Kasus pada Illegal Occupation di Tahura Ngurah Rai”, Tesis, Program Studi Magister llmu Hukum Program Pascasarjana Universitas Udayana, Denpasar

Undang-Undang Pokok Agraria (UU No 5 Tahun 1960

Undang-Undang tentang Kehutanan (Undang-Undang No. 41 tahun 1999 Undangt-undang tentang Sumberdaya Air 
(UDAYANA MASTER LAW JOURNAL)

(Undang-Undang Republik Indonesia

Nomor 7 tahun 2004)

Undang-Undang tentang Pertambangan,

Mineral dan Batubara (Undang-

Undang Republik Indonesia nomor 4 tahun 2009)

Undang-Undang tentang Perikanan (UU No 45 tahun 2009).

Undang-Undang tentang Pengelolaan Wilayah Pesisir dan Pulau-Pulau Kecil (UU No.1 tahun 2014 